\title{
The Development of A Fairy Tale Text Learning Model Using Problem Based Learning Approach in Class IV Elementary School
}

\author{
Mursal $^{1}$, Syahrul Ramadhan ${ }^{2}$, Ermanto $^{3}$ and Atmazaki ${ }^{4}$
}

\author{
${ }^{1}$ Universitas Negeri Padang, Padang, Indonesia, ه(email), mursalinmahyudin@ gmail.com \\ ${ }^{2}$ Universitas Negeri Padang, Padang, Indonesia, $ه$ (email), syahrul@fbs.unp.ac.id. \\ ${ }^{3}$ Universitas Negeri Padang, Padang, Indonesia, $\nabla$ (email), ermanto@fbs.unp.ac.id \\ ${ }^{4}$ Universitas Negeri Padang, Padang, Indonesia, $ه$ (email), atmazaki@fbs.unp.ac.id
}

\begin{abstract}
The background of this study is due to the low ability of students in writing fairy-tale texts accompanied by personal opinions. This type of research is research and development. The development model in this research is to use a model developed by Thiagarajan, which consists of four stages of development, namely define, design, develop, and disseminate. The results of the study show that the developed Fairy Tale Text Learning Model meets the aspects of validity, practicality, and effectiveness.
\end{abstract}

\section{Keywords: Writing, Primary School, Learning Model, Problem Based Learning}

\section{INTRODUCTION}

Lack of students' skills in writing is due to limited knowledge and mastery of paragraphs, effective use of sentences, use of vocabulary, and use of spelling and punctuation marks (Rukayah, 2014). Teachers need to provide opportunities for students to continue to improve their writing by doing frequent exercises. Students will reflect on the results of writing, evaluate, and improve it themselves (Xin, 2007). Students' confidence needs to be built in order to get better writing results (MacDuff, Khadija, \& Caroline, 2010). The teacher tries to make students feel happy with what has been written and not embarrass the students' writing. Students do not need to feel afraid, but give students the opportunity to appreciate the results of their writings (Gair, 2015). The results of students' writing that have been made are checked by the teacher, then counted how much time is spent on writing, whether sufficient or not (Gilbert and Steve, 2010). Teachers need to provide sufficient time so students can complete their writing assignments well (Noor and Yusof, 2016).

The teacher's effort in teaching students is an important part in achieving the success of the planned learning writing goals. One such effort is the selection of various learning models. The right learning model can increase the activities of students in writing, and it is expected that teachers can choose various learning models that are adjusted to the level of student development.

Some of the things discussed in this paper are; a) What is the process of developing a model of learning to write fairytale text based on problem based learning for grade IV students of Primary Schools? b) How is the quality of the learning model of writing fairytale-based text problem-based learning for grade IV students of Primary Schools in terms of validity, practicality, and effectiveness?

Teachers should view themselves as writers, and can play an important role in helping students to be able to write (Zorch, Myers, Lambert, Vetter, and Faibanks, 2016). In turn, school teachers need better preparation for teaching writing (Kane, 2016). Teachers who teach writing in principle give and receive feedback from students about writing (Fallon and Whitney, 2016). Elementary School teachers must understand and be able to teach writing (DeFauw and Smith, 2016).

Based on the opinion of the experts above, it can be concluded that writing is an activity of describing graphic symbols and expressing ideas through language media.

Text-based learning can be understood from each of the words. For more details, we will first explain the meaning of 'learning'. Language Board (2008: 23) states that learning is trying to gain intelligence or knowledge. Then learning is the learning process. Next 'base' according to the Language Board $(2008 ; 144)$ is the principle or basis. The word 'principle' is interpreted as a basis (something on which thought or opinion is based). Then the basic word is interpreted as a base; foundation or principal or base of an opinion (teachings, rules). 
Case studies of problem based learning include: 1) presentation of problems, 2) driving inquiries, 3) steps of problem based learning namely initial analysis, raising learning issues, independence literacy and collaborative problem solving, integration of new knowledge, presentation of solutions and evaluation (Rusman, 2012: 233).

The main purpose of problem-based learning is not to convey a large number of facts to students, but rather to develop students' ability to think critically, solve problems, and at the same time develop their knowledge. Problem-based learning is also intended to develop learning independence and social skills of students that can be formed when students collaborate in identifying information, strategies, and learning resources that are relevant for solving problems (Priyatni, 2015: 112).

\section{METHOD}

This type of research is research and development. Research and development is research that conducts investigative activities to develop existing products or procedures. Research and development has occupied a very meaningful position, both in the business world and in the fields of science, technology, social sciences and humanities (Yusuf, 2014: 444-445). Based on Joseph's opinion in conducting research and development, an investigation must be carried out first, after that new products can be developed based on the results of the investigation conducted.

The development model in this study is to use a model developed by Thiagarajan, et al (1974). The model consists of four stages of development, namely define, design, develop, and disseminate or in Indonesia into $4 \mathrm{P}$, namely defining, designing, developing, and disseminating. Further explanation regarding the four stages is as follows:

\section{Defining Phase}

The definition phase aims to obtain data that is useful for designing research products in order to solve the problem of learning to write a fairy tale text based on problem based learning. The method used in the defining stage is conducting interviews with teachers, students, and analysis by researchers themselves.

\section{The Design Phase}

The purpose of this design stage is to prepare a model of learning to write fairytale text based on problem based learning based on data at the defining stage. The writing learning development model that is designed is, Teacher's Book and Student's Book.

3. Development Phase

The purpose of this development stage is to test the validity, practicality test, and test the effectiveness of learning to write fairytale-based text problem-based learning. Each of the tests of validity, practicality, and effectiveness were revised.

\section{Disseminate Phase}

The purpose of the dissemination stage is to disseminate the products that have been developed and ask for comments on the products that have been developed.
The way to do this at the dissemination stage is to ask for opinions from teachers and students in class IV Elementary School after using the book. The teacher is asked for his opinion about the Teacher's Book and Student's Book.

The type of data taken in this study is qualitative and quantitative data. Qualitative data were obtained from interviews with students, as well as analyzes conducted by researchers themselves on learning to write. The types of qualitative data in this study are defining data. While quantitative data obtained from the source, namely students in the form of data, namely; 1. Data on the validity of teacher's books, 3. Data on the validity of students 'books, 4. Data on the practicality of teacher's books, 5. Data on the practicality of students' books, 6 . Data on teacher's book dissemination, and 7. Student's book's dissemination data.

Data analysis techniques in this study were divided into two kinds, namely qualitative data analysis and quantitative data analysis. Qualitative data analysis using the flow model, its components consist of data reduction, data presentation, and drawing conclusions (Miles and Huberman, 1994: 10).

\section{RESULT AND DISCUSSION}

\section{Defining Phase}

At this stage of defining there are five steps that must be passed namely the initial initial analysis, student analysis, concept analysis, task analysis, and compiling learning objectives.

2. The Design Phase

After all the data from the defining stage consisting of the initial initial analysis, concept analysis, task analysis, arrangement of learning objectives, and mastery of literature have been completed, all the data are used as the basis for designing the three research products in this dissertation, namely a book model entitled Text Learning Fairy Tales, a teacher's book entitled Guidelines for Learning Fairy Tales, and a student's book entitled Let's Learn Fairy Tales.

3. Development Phase

At the development stage, the validity test of the product that has been developed is tested. Before the validity test is done, a validator of the fairytale text learning model must be determined first.

4. Disseminate Phase

The dissemination phase is carried out with the intention to spread the fairy tale text learning model and solicit opinions from teachers and students using the model. Dissemination in this study was limited to class IV.

All grades of IVA class obtained in three time, then added up and shared with many students to get an average grade. The average value obtained is not only the value of learning outcomes, but also the value of attitude. Judging from the table, the average value of IVA class students' attitudes with a value of 83 . The value of 83 is included in the effective level. The meaning is that students' attitude value for 3 meetings has been effective. From the data of students' attitudes that have been 
effective it also shows that learning with a fairytale text learning model during 3 learning meetings by students is in the effective category.

Product revision of the next research is based on suggestions given by students, when the trial is carried out after the instrument is given the student's practicality. The advice given is to add a green color to the student's book because the color is beautiful to the eye and natural.

The Story Book Text Learning model was developed based on several theoretical references. Theories included in the Book of the Story Telling Textbook model for example the theory of Joyce \& Weil. Joyce \& Weil states that the learning model is a plan that is used as a guide in learning. The learning model consists of syntax, social systems, principles of reaction, support systems, instructional effects and nurturant effects. As for model book that the author has developed has included aspects of the learning model above.

At development stage, the validity test of the product that has been developed is tested. Before use all product validation instruments developed validated was performed by three validators. Validation results of the Story Book Texture Model Book is 3.96, this value is included in the valid level. While the value of the results of the validation of the Story Book Teacher Guidance in Texts is 3.88 with a very valid category.

Furthermore, Students' Books Let's Learn Fairytale Texts validation was also carried out by three validators, the validator results are obtained is 3.95 are valid. Research products in the form of model books, teacher books, and student books are at a valid level.

Practicality trials get results that is the practicality of teacher books according to the teacher in the percentage of 100 and categorized as very practical. Whereas for the students 'books the practicality level of the students' books according to students in percentage is 94.80 and categorized as practical level. Judging from the results obtained from the model books, teacher books, and student books are in the practical level.

The practicality test that has been conducted in research, matches what Joyce \& Weil said, that the difficulties experienced by students during the learning process will be overcome by having a neatly arranged learning model.

After the experiment was obtained the learning outcomes of IVA class students were 85.2 with the effective category. From the two values, it can be seen that the average value of learning outcomes in class IVA (experimental class) is higher than class IVB (control class).

Based on the average value of learning outcomes of IVA and IVB grade students, all IVA and IVB grade students have completed their learning outcomes in fairy tale text material. To test the learning model of fairytale text with conventional learning models it is necessary to do a t test on the average value of learning outcomes of students in class IVA (experimental class) and IVB (control class). Based on the data table, with a significance of 0.025 obtained $t$ count $>t$ table $(9,692>2000)$ then H1 is accepted, it means that the learning outcomes of students in fairy-tale text material from students taught with fairy-tale text learning models are higher than the learning outcomes of students at Fairytale text material from students who are taught with conventional learning models.

The fairytale text learning model has been going according to plan and getting effective results. According to Pribadi (2010: 86) effective learning is obtained from a well-structured learning model. Effective learning activities will bring students to a better understanding.

Dissemination is done in class IVA for three learning meetings. According to the teacher teaching in class IV, the level of ease in using the teacher's book is 96.43 and is categorized as very easy to use. The teacher is easy to understand at each stage so that learning runs smoothly. Whereas for student books the level of ease of spreading student books by percentage is 96.05 and categorized as very easy to use. Students easily understand the material and assignments that must be done.

\section{CONCLUSION}

After the defining step is continued with the step of designing the learning model of dogeng text which consists of three books, namely the book model of learning fairy-tale text, the teacher's guide book of learning fairytale text, and the book of students let's learn fairy-text. In the design step the instrument was also developed to validate the three research products. Before the instrument is used first, the instrument is validated.

After completing the design phase, proceed to the development stage. At this stage of development, validation of the three products in this study and improvements made to the suggestions given by the validator. At this stage, practicality and effectiveness of the learning model of fairy-tale text learning models in class IVA and IVB were also conducted. The last stage of this research is the dissemination stage. Before disseminating, an instrument for the dissemination stage is made and validation of the instrument is made before being used in the dissemination class.

\section{REFERENCES}

11] Badan Bahasa. 2008. Kamus Besar Bahasa Indonesia. Edisi Keempat. Jakarta: PT Gramedia Pustaka Utama.

[2] DeFauw, Danielle L \& Smith, Mellisa. (2016). Writing for an Authentic Audience - One Teacher-Writer's Narrative Journey. The Journal of Writing Teacher Education. 5(1), 105-126

[3] Fallon, Lochran C., Whitney, Anne Elrod. (2016). "It's a Two-Way Street": Giving Feedback in a Teacher Writing Group.The Journal of Writing Teacher Education. 5(1) 61-73

[4] Gair, Marina. (2015). Slaying the Writing Monsters: Scaffolding Reluctant Writers through a Writing Workshop Approach. 
International Journal of Teaching and Learning in Higher Education, 27(3), 443-456

[5] Gilbert, Jennifer \& Graham, Steve. (2010). Teaching Writing to Elementary Students in Grades 4-6: A National Survey. The Elementary School Journal, 110(4),495-517

[6] Joyce, Bruce.,Weil, M., \& Calhoun, E.(2009). Models of Teaching. Terjemahan oleh Achmad Fawaid\&Ateila Mirza. Yogyakarta: PustakaPelajar

[7] Kane, BritnieDelinger. (2016). Developing Preservice Writing Teachers' Professional Judgment: Design Conjectures for Supporting Equitable and Rigorous Writing Instruction. The Journal of Writing Teacher Education. 5(1) 37-59

[8] MacDuff, Fife., Al Hayki, Khadija., \&Linse, Caroline. (2010). Using Progressive I-Can Statements to Promote Learner Confidence in Writing. English Teaching Forum. 4, 2-11

[9] Miles, Matthew B danHuberman, A Michael. 1994. Qualitative Data Analysis, Second Edition. California:Sage Publication.

[10]Noor, Muhammad \&Yusof, Nurahimah Muhammad. (2016). Improving Process Writing with the Use Authentic Assesment. International Journal of Evaluation and Research In Education, 5(3),200-204

[11] Pribadi, Benny A. (2010). Model Desain Sistem Pembelajaran. Jakarta: Dian Rakyat

[12] Priyatni, Endah Tri. (2015). Desain

[13]Pembelajaran Bahasa Indonesia Dalam Kurikulum 2013, Jakarta: BumiAksara

[14]Rukayah. (2014). The Writing Skill of $3^{\wedge}$ th Grade Students of Sibulue Subdisctrict Junior High School of Bone Regency. International Journal of Linguistics, 6(2), 239-257

[15]Rusman.(2012). Model-model Pembelajaran; Mengembangka nProfesionalisme Guru. Jakarta: RajaGrafindoPersada

[16] Thiagarajan, Sivasailam, dkk. (1974). Instructional Development for Training Teachers of Exceptional Children: A Sourcebook. Washington, D.C: Indiana University, Bloomington.

[17]Xin, Zhuang. (2007). Reflective Thinking on Communicative Teaching in Writing.Volume 4, No.5 (Serial No.30) US-China Education Review, 4(5), 19-25

[18]Zorch, Melody., Myers, Joy., Lambert, Claire., Vetter, Amy., \&Faibanks, Colleen. (2016). Reimagining Instructional Practices: Exploring the Identity Work of Teachers of Writing. The Journal of Writing Teacher Education. 5(1)124 